\title{
Fracturing の際の砂の運動についで
}

\author{
柴宮博** \\ Movement of Hydraulic Fracturing Sand*
}

by Hiroshi Shibamiya**

\begin{abstract}
Summary : Hydraulic fracturing makes the very permeable channel, where the fracture is created in the reservoir formation by the injection of fluid suspending sand with high pressure and high rate and then the openning of fracture is filled up with sand carried in the fracturing fluid, for the purpose of elevating the productivity or flowing capacity of oil reservoir. Therefore, the study on the movement of sand during the fracturing procedure, especially transportation and deposition of sand in the fracture openning, is thought to be very useful for understanding of fracturing process and promoting its effectiveness.

This paper states, first, the experimental and theoretical studies on the precipitation of sand grains in the non-flowing fluid and experiment of sand movement in the flowing fluid in the fracture openning, which is represented by the model apparatus. The sand mixed in the flowing fluid precipitates and deposits to the bottom of channel because of gravity segregation, when the flow rate is low. But when the flow rate reaches to the certain degree, the equilibrium is obtained such as no more precipitation of sand occures nor the previously deposited sand moves. The velocity of this state is defined as equilibrium velocity. This paper reveals the equilibrium velocities, which are obtained experimentally for sands in water, medium weight crude oil and the gel fluid and discussion about movement and deposition of sand in the fracture openning by application of those data. Furthermore, a few points, which should be considered carefully at the fracturing practices, are induced.
\end{abstract}

\section{1. 緒言}

Hydraulic Fracturingは，圧入流体に砂を混入，惩垂し， これを高圧高速で油層に圧入して，油層にキ裂を生じさせると ともに，キ裂の中に流体によって砂を運び込んで充テンして， キ裂が復元闒りクするのを防いで，浸透性の大きい通路を油首 内に作ることによって油居の産出能力を高めるととを目的とし ている。したがって Fracturing 作業中の砂の動き，特にキ裂の 中にはいってからの砂の流動状况を検討することは，Fracturing の実態を把握し，その効果の增大を計る上に最もたいせつ な問題の一つであると考える。しかしながら，キ裂の中におけ ろ圧入流体の流動状態は，きわめて複雑であり，したがって砂 の流動状態もまた解析がきわめて困難であるので，本文では問 題をきわめて単純化した状態のるとに仮定して検討し，また地 層のキ裂に類似した装置を作って，その中て砂を流動させて実 験し，てれによってキ裂内における砂の運動に関してなんらか の傾向を求めるてとにつとめた。もちろん，まだ実験の䇶囲は 狭く，検討も基䂵的な筑围を出ないものであるけれども，いち おうの基整的なまとまりはつけられたものと思う。将来は，本 文にわいて検討した結果を実際の作業に反映させ，また実際の 作業より得た経験によってての問題の解析をさらに深くかつ広 く押し進めてゆきたいと考えている。

* 昭和 35 年 10 月 17 日受理

** 帝国石油株式会社 Teikoku Oil Co., Ltd.

\section{2. フラク砂の静止流体中における沈降について}

Fracturing 作業中のキ裂内において流動中の砂に醌く力は， 二つの分力をもっている。その一つは重力の作用で下方に向う 分力であり，他の一つはキ裂内を流れる流体の流れによって水 平方向に動てうとする分力である。フラク流体によって運ばれ た砂が、キ裂の中に沈着しタイ䅡して sand bed を作るのは，す へててこの下方に向う分力によっておてるのである。したがって， Fracturing 作業中の砂の流動状態を明らかにするためには， まず静止流体中における砂粒の沈降状指から検討することが必 要となってくる。

\section{1 静止流体中の眇粒の沈降速度の测定}

フラク砂か瀞止している流体中をいかなる速度で沈降するか そついて実測した。

部料

フラク砂として使用されている久の浜ヶ砂の 20〜30×ッ シュ，30〜40 メッシュとして調製されたものを，重量比で 1: 1 の割合で混合し, ASTM No. 20 40 の標準フルイで六つの グループにフルイ分けしたものを使った。

\section{実験装置}

図 1 亿示すように適当な刻線を施したガラス円筒を用いて， 砂粒を 1 粒ずつ落下し，刻線を通過するに要した所要時間をス トップウォッチで测定しだ。

実験方法 


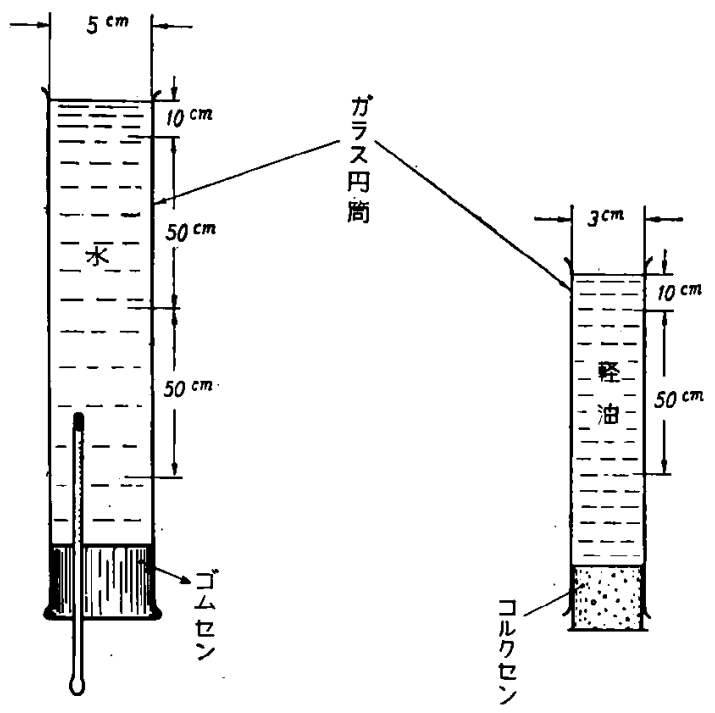

田 1

（1）水中の沈降速度測定

（1）第 1 の刻楾より $50 \mathrm{~cm}$ 沈降す万所要時間と, $1 \mathrm{~m}$ 沈 降するそれとを測定、後者が前者の 2 倍にあたるかを調べ た。

（口）五色砂といわれろ久の浜ケイ砂を色別に選別し，各 粒径, 各色ことに粒子 20 コあてを水中に沈降させて, その 比降速度を测った。

\section{（2）軽油中の沈降速度の測定}

（イ）軽油の比重および粘度の測定（オストワルド粘度計 No. 23)

（ロ） $50 \mathrm{~cm}$ の軽油中を砂粒 1 粒ずつ落下させ，所要時間 を測定, 沈降速度を算出した。各大きさの砂柆について20コ ずつの粒を用いた。

\section{実臨䊅果}

（1）水中の沈降速度

ストップウォッチ 2 コを用い, 砂粒 1 粒が第 1 の刻線を通過 して $50 \mathrm{~cm}$ 沈降する時間と, $1 \mathrm{~m}$ 沈降する時間を記録し，後 者が前者の 2 倍であることを確認した。なおこの実験によっ て，沈降する粒子が水中て定常落下速度に達するに要する時間 は意外に早く，またその距離は約 $10 \mathrm{~cm}$ で足りるとともわか ot。

各粒徍，各色別の砂の沈降所要時間わよびその速度は表 1 の とおりである。

\section{表 1 础の水中の沈降速度実測值（測定時の水温 $14.5 \sim 17.0^{\circ} \mathrm{C}$ )}

\begin{tabular}{|c|c|c|c|c|c|c|c|c|}
\hline \multirow[b]{2}{*}{$\begin{array}{l}x_{2} \\
i=1\end{array}$} & \multirow{2}{*}{ 柆 $\mathrm{cm}$} & \multicolumn{4}{|c|}{ 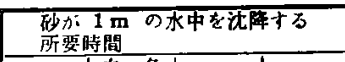 } & \multirow{2}{*}{ 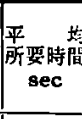 } & \multicolumn{2}{|c|}{\begin{tabular}{|l} 
永中の沈降 \\
速度
\end{tabular}} \\
\hline & & $\mid \begin{array}{c}\text { 白色政明 } \\
\sec \end{array}$ & $\begin{array}{l}\text { 香觔 } \\
\text { sec }\end{array}$ & $\begin{array}{c}\text { 黑 色 } \\
\text { sec }\end{array}$ & $\begin{array}{l}\text { その他 } \\
\text { sec }\end{array}$ & & $\mathrm{cm} / \mathrm{sec}$ & $\mathrm{ft} / \mathrm{m}$ \\
\hline 20 & $\sim 0.084$ & 8.7 & 9.2 & 8.1 & 8.5 & 8.6 & 11.6 & 22.8 \\
\hline 25 & $0.08 \propto \sim 0.071$ & 9.5 & 9.1 & 9.4 & 9.1 & 9.3 & 10.8 & 21.2 \\
\hline 30 & $0.01 \sim 0.059$ & 11.4 & 11.0 & 10.6 & 10.0 & 11.0 & 9.1 & 17.9 \\
\hline 35 & $0.059 \sim 0.050$ & 13.7 & 13.3 & 13.0 & 13.1 & 13.3 & 7.5 & 14.8 \\
\hline 40 & $0.050 \sim 0.042$ & 15.8 & 15.5 & 15.5 & 16.1 & 15.7 & 6.4 & 12.6 \\
\hline $40+$ & $0.042 \sim$ & 18.8 & 18.3 & 16.4 & 19.0 & 18.2 & 5.5 & 10.8 \\
\hline
\end{tabular}

\section{（2）軽油中の沈降速度}

軽油の粘度は, オストワルド粘度計 No. 23 を用いて, 各温 度にわいて 5 回測定し, 平均值を求めた。
表 2 軽油の粘度と比重实測值

\begin{tabular}{cr|c|c|c}
\hline \multicolumn{2}{c|}{ 温 度 ${ }^{\circ} \mathrm{C}$} & 12.5 & 14.5 & 20.5 \\
\hline \multicolumn{2}{l|}{ 軽油粘度ボイズ } \\
\multicolumn{2}{l|}{ 比 } & 0.0214 & 0.0195 & 0.0146 \\
\hline
\end{tabular}

埕油中の砂粒の沈降速度の実测には，砂粒を色分けすること なく，各粒径の武料 20 粒ずつを用いて，桯油中を砂粒か 50 $\mathrm{cm}$ と $1 \mathrm{~m}$ 沈降するに要する時問を測定した。測定結果は表 3 のとおりである。

表 3 砂の軽油中の沈降速度実測值

\begin{tabular}{c|c|c|c|c}
\hline \multirow{2}{*}{ フルイ番号 } & \multicolumn{2}{|c|}{ 沈降所要時間 } & \multicolumn{2}{|c}{ 沈 降 速 度 } \\
\cline { 2 - 5 } & $50 \mathrm{~cm}(\mathrm{sec})$ & $1 \mathrm{~m}(\mathrm{sec})$ & $\mathrm{cm} / \mathrm{sec}$ & $\mathrm{ft} / \mathrm{m}$ \\
\hline 20 & 4.2 & 8.4 & 11.9 & 23.4 \\
25 & 5.0 & 10.0 & 10.0 & 19.7 \\
30 & 5.4 & 10.8 & 9.3 & 18.3 \\
35 & 6.4 & 12.8 & 7.8 & 15.3 \\
40 & 8.0 & 16.0 & 6.3 & 12.4 \\
$40^{+}$ & 9.1 & 18.2 & 5.5 & 10.8 \\
\hline
\end{tabular}

\section{2 液体中の眇の沈降速度の計算法}

流体の中で運動する粒子の運動に対する流体の抵抗を $f$ とす れば,レイノルズ数 $2 r V \rho_{2} / \mu<1$ のときにはストークスの法 則

$$
f=6 \pi r \mu V
$$

が成立するが， $2 r V \rho_{2} / \mu=30 \sim 300$ の場合にはアレンの法則

$$
f=\frac{5}{4} \pi(2 r V)^{1.5}\left(\rho_{2} \mu\right)^{0.5}
$$

が成立する゙)。とこに，fは流体の抵抗（ダイン $\mathrm{g} \cdot \mathrm{cm} / \mathrm{sec}^{2}$ ) $r$ は球の半径 $(\mathrm{cm})$ $\mu$ は液体の粘度（ポイズ $\mathrm{g} / \mathrm{cm} ・ \mathrm{sec}$ ) $V$ は粒子の速度 $(\mathrm{cm} / \mathrm{sec})$ $\rho_{1}$ は粒子の密度 $\left(\mathrm{g} / \mathrm{cm}^{3}\right)$ $\rho_{2}$ は流体の密度 (") $g$ は重力による加速度 $\left(\mathrm{cm} / \mathrm{sec}^{2}\right)$

\subsection{1 粘度の小さい流体中の砂の沈降速度の計算}

レイノルズ数を計算したとてろ約 100 であったから，てれは 中間粒子として, 前記の (2) 式を適用する。粒子に対する下 向きの力は $4 / 3 \pi r^{3}\left(\rho_{1}-\rho_{2}\right) g$ であるから，

$$
\begin{aligned}
& \frac{5}{4} \pi(2 r V)^{1.5}\left(\rho_{2} \mu\right)^{0.5}=\frac{4}{3} \pi r^{3}\left(\rho_{1}-\rho_{2}\right) g \\
& \left(\frac{5}{4}\right)^{2}(2 r V)^{3}\left(\rho_{2} \mu\right)=\left(\frac{4}{3}\right)^{2} r^{6}\left(\rho_{1}-\rho_{2}\right)^{2} g^{2} \\
& V^{3}=\frac{\frac{16}{9} r^{3}\left(\rho_{1}-\rho_{2}\right)^{2} g^{2}}{\frac{25}{16} \times 8 \times \rho_{2} \mu} \\
& V=\left\{\frac{16 \times 16}{25 \times 8 \times 9} \cdot \frac{\left(\rho_{1}-\rho_{2}\right)^{2} g^{2}}{\rho_{2} \mu}\right\}^{1 / 3} r \\
& =\left\{\frac{4}{225} \cdot \frac{\left(\rho_{1}-\rho_{2}\right)^{2} g^{2}}{\rho_{2} \mu}\right\}^{1 / 3} 2 r
\end{aligned}
$$

計算にあたっっては，砂粒の形は完全球体であると仮定し，また 温度による密度の変化は無視した。使用した数值は次のとおり である。

粒径 $d=0.042 \sim 0.084 \mathrm{~cm}$

落化球体 (砂粒) 密度 $\rho_{1}=2.64 \mathrm{~g} / \mathrm{cm}^{3}$ 
液体の密度 $\rho_{2}$ は水 $=1.00$, 根油 $=0.81$, 八橋原淅 $=0.84$ $\mathrm{g} / \mathrm{cm}^{3}$

液体の粘度 $\mu$ は水 $=0.01$, 軽油 $=0.015$, 原油 $=0.042 \mathrm{~g} /$ $\mathrm{cm} \cdot \mathrm{sec}$

計算結果は表4のとおりであった。

表4 粘度の小さい流体中の础の沈降逃度の計算值と 実測値との比㜞

\begin{tabular}{|c|c|c|c|c|}
\hline $\begin{array}{l}7 \mu 1 \\
\text { 7番号 }\end{array}$ & 砂粒值径 & $\begin{array}{l}\text { 計算に上京定常 } \\
\text { 洛速度 } \mathrm{cm} / \mathrm{sec}\end{array}$ & 实 测 & 值 \\
\hline \multicolumn{5}{|c|}{$20^{\circ} \mathrm{C}$ の水中における定常沈降速度 } \\
\hline 20 & $\sim 0.084^{\mathrm{cm}}$ & $\begin{array}{r}\mathrm{cm} / \mathrm{sec} \\
\sim 13.94\end{array}$ & $\begin{array}{l}\mathrm{cm} / \mathrm{sec} \\
11.6\end{array}$ & 22.8 \\
\hline 25 & $0.084 \sim 0.071$ & $13.94 \sim 11.78$ & 10.8 & 21.2 \\
\hline 30 & $0.071 \sim 0.059$ & $11.78 \sim 9.79$ & 9.1 & 17.9 \\
\hline 35 & $0.059 \sim 0.050$ & $9.79 \sim 8.30$ & 7.5 & 14.8 \\
\hline 40 & $0.050 \sim 0.042$ & $8.30 \sim 6.97$ & 6.4 & 12.6 \\
\hline $40^{+}$ & $0.042 \sim$ & $6.97 \sim$ & 5.5 & 10.8 \\
\hline \multicolumn{5}{|c|}{$20^{\circ} \mathrm{C}$ の軽油中における定常沈降速度 } \\
\hline 20 & $\sim 0.084$ & $\sim 14.08$ & 12.2 & 23.4 \\
\hline 25 & $0.084 \sim 0.071$ & $14.08 \sim 11.90$ & 10.0 & 19.7 \\
\hline 30 & $0.071 \sim 0.059$ & $11.90 \sim 9.99$ & 9.3 & 18.3 \\
\hline 35 & $0.059 \sim 0.050$ & $9.99 \sim 8.38$ & $7.8^{n}$ & 15.3 \\
\hline 40 & $0.050 \sim 0.042$ & $8.38 \sim 7.04$ & 6.3 & 12.4 \\
\hline $40^{+}$ & 0.042 & $7.04 \sim$ & 5.5 & 10.8 \\
\hline \multicolumn{5}{|c|}{$23.5^{\circ} \mathrm{C}$ の八橋原油中における定常沈降速度 } \\
\hline 20 & $\sim 0.084$ & $\sim 9.74$ & \multirow{6}{*}{ 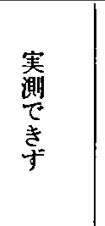 } & \\
\hline 25 & $0.084 \sim 0.071$ & $9.74 \sim 8.24$ & & \\
\hline 30 & $0.071 \sim 0.059$ & $8.24 \sim 6.84$ & & \\
\hline 35 & $0.059 \sim 0.050$ & $6.84 \sim 5.80$ & & \\
\hline 40 & $0.050 \sim 0.042$ & $5.80 \sim 4.87$ & & \\
\hline $40^{+}$ & $0.042 \sim$ & 4.87 & & \\
\hline
\end{tabular}

以上の結果により，水中および軽油中における砂粒の沈降速度 の計算值と実椡值が比較的よく一致していることがわかる。図 2 亿軽油および原油 $\left(23.5^{\circ} \mathrm{C}\right)$ 中の砂の沈降速度の計算值と砂の 粒径との関係を図示した。これらはいずれも面線関倸にある。

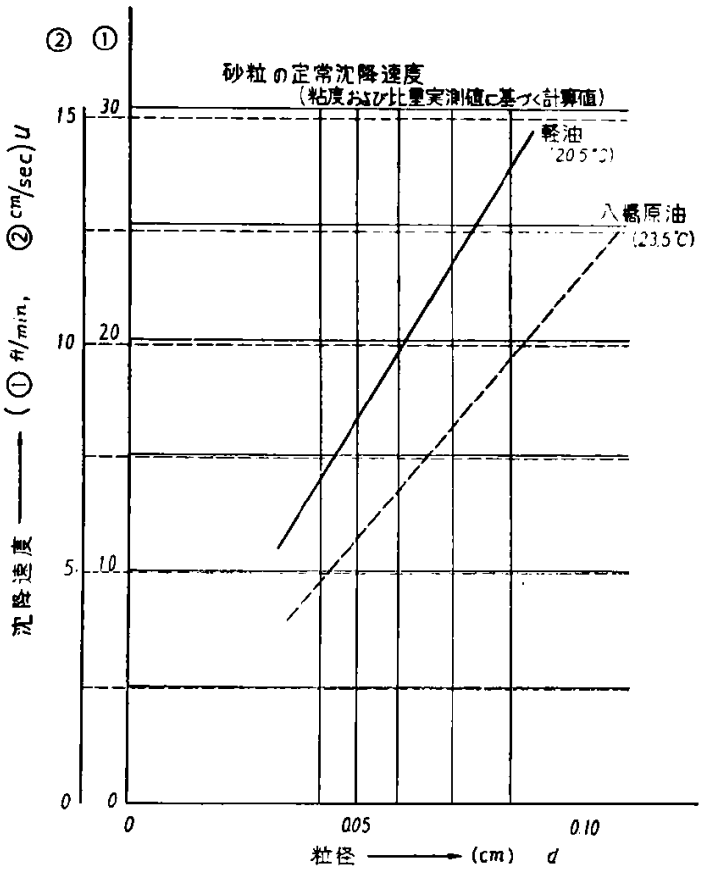

因 2 砂粒の粒径と沈降速度との関係

\subsection{2 粘度の大きい流体中の砂の沈降速度の計算}

比重 0.933 ,粘度 $150 \mathrm{cp}$ の重油の中を砂を沈降させる場合を 考えるととにし，まずレイノルズ数を計算するととれが約 0.7 となり、1よりも小さい值なので，ストークスの法則が適用さ れるととを知る。したがって

$$
f=6 \pi r \mu V
$$

したがって前節の場合と同じように

$$
6 \pi r \mu V=4 / 3 \pi r^{3}\left(\rho_{1}-\rho_{2}\right) g
$$

ゆ元に, $V=\frac{2 g r^{2}\left(\rho_{1}-\rho_{2}\right)}{9 \mu}(\mathrm{cm} / \mathrm{sec})$

この式によって各サイズの砂が，比重 0.933 , 粘度 $150 \mathrm{cp} の$ 重油の中を沈降する場合の沈降速度を計算すれば表 4 のとおり である。

\begin{tabular}{|c|c|c|c|c|}
\hline フルイ番号 & 沈 & 降 & 速 & 度 \\
\hline 10 & \multicolumn{2}{|c|}{$2.52 \mathrm{~cm} / \mathrm{sec}$} & & $4.96 \mathrm{ft} / \mathrm{min}$ \\
\hline 16 & \multicolumn{2}{|l|}{0.89} & & 1.75 \\
\hline 20 & \multicolumn{2}{|l|}{0.44} & & 0.87 \\
\hline 25 & \multicolumn{2}{|l|}{0.32} & & 0.63 \\
\hline 30 & \multicolumn{2}{|l|}{0.22} & & 0.43 \\
\hline 40 & \multicolumn{2}{|l|}{0.11} & & 0.22 \\
\hline
\end{tabular}

表 4 原油中の砂の沈降速度

\section{3. キ裂内における砂の流動について}

キ裂の中に，砂と流体がある一定のレートで王入され流動し ている場合の, 砂の運拲について考える。流体の中の砂は此重 が大きいので，流体の中で地降して底に沈む。流秒中の流体の 中の砂は必ず讯降する。たとえ静止状胉では全く砂が沈まない ようなゲルの中でも，このゲルが流動中には砂忚泩する。さ

て，最初流体のキ裂内の流速が小さいときには，砂はしだいに キ裂の底に沈んでだりりだんだん積ってキ裂の断面積を縮め ろので流体の流速はそれに伴ってしだいに速くなり，流速があ る限界点に達すると，それ以後に流入した砂は全部流体ととも に流れ去るようになるが，先に沈殿している砂はその場所から 動かない。このとき砂の混合率を增㖪せず，流体の圧入レート を增加して，キ裂内の流速を大きくしてやろと，先に既跑して いた砂が少しずつ流れ去り，しだいに流動断面積が大きくな る。かくして流速がしだいに小さくって，ついある限界点 に注すると，流入する仯は全部流れ去るが比㷉していた砂はる れ以上は敞れなくなる。このように砂の流動に対してある限界 速度があることが楒めら机るが，との限界点というのは，その ときの旅動系統が自動的に求めたととろの平衡点であって，し たがっててときの速度を平衡速度 (equilibrium velocity) と いう。平衡速度は，流体の此重, 粘度, 砂の大きさ，比重およ びその混入率によって影䱥をうけるものと考えられる。

\section{1 水を流体とした場合の平衡速度の実硂}

\section{1 .1 装是およひ実倹方法}

キ裂の中の砂の流動状況を見るための実験として，地風のキ 裂に類似したものを作り，この中で砂を流動させて夷跧した。 砂の流動状況をよく見ることができるためには，キ裂は水平の ちのよりも垂直のもののほうが都合がよいので，垂直キ裂の模 型を作った。実験装膡の略図を図 3 亿示すが，無色透明のアク 


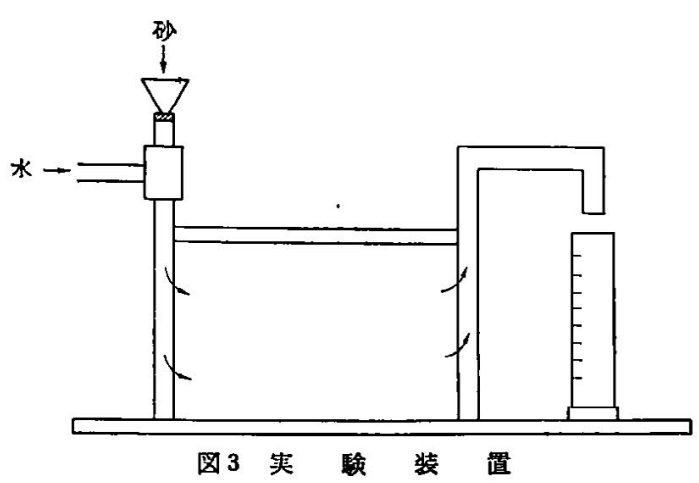

リル樹脂板を 2 枚, 間隔 $1 \mathrm{~cm}$ で平行して垂直に立てて垂值の キ裂を模し，板の上端と下端はふさいでおき，片方の端から水 または水と砂を流入し，他方の椯から流出するようにした。実 験の第 1 は水と砂とをある一定の割合で混合しながら流入し て，キ裂内での砂の沈皘状沉を見たのであるが，とのときは， 置の中の砂混合用口ートより砂を落下しながら水を一定レー トで流し，時間の経過に対するキ裂内での砂の沈積状況を写真 に撮った。また砂がそれ以上沈積せずに水平に流動しはじめる ときの流速を测定して，てれをもってそのときの条件下での平 衙速度とした。次に第 2 の実験として，キ裂の中にあらかじめ 砂を入れてピラミット状にその頭部がキ裂の頂部にまで達する ようにしておき，乙れに水を流入して，砂を加えない水のみの 流動のときの平衡速度を測定した。

\section{1 .2 実験結果}

\section{実験第 1 水と秒とを混合して流入した場合}

砂には久の兵ヶ1砂の 10〜20, 20〜30, 30〜40 メッシュの 3 種類の砂を使った。砂の沈積の状況は各サイズの砂とも皆同 しような傾向を示したので，10〜20メッシュの砂についてそ の概略を述べることにする。

砂は $235 \mathrm{~g} / l$ すなわち $1.96 \mathrm{lb} / \mathrm{gal}$ の割合で水に混入した。 水は水道の水を用い, 水の流入レートは $27.2 \mathrm{cc} / \mathrm{sec}$, 換算すれ ば $0.0103 \mathrm{bbl} / \mathrm{min}$ であった。キ裂の断面積に比して水の砂入 レートが低いので仯はキ裂の中にはいるとすぐに沈積をはじめ た。図 4-1 に流入開始 $30 \mathrm{sec}$ 後の状態を示す。水とともに キ裂にはいる砂は，先に沈積している砂の上にしだいに積り， しだいにその高さと奥行きとを增加した。图 4-2 は流入開 始 $1 \mathrm{~min}$ 後の状態である。このようにしてしだいに砂の高さ

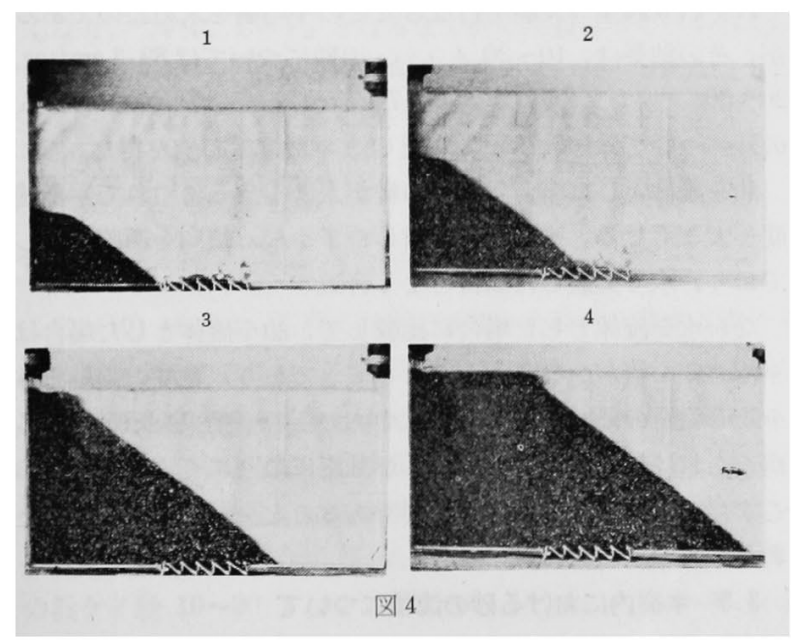

が增し，砂の頂部とキ裂の上端との間隔が狭くなるにつれて， この間を通る水の速度が増加した。そしてついに流入開始 2 $\min 30 \mathrm{sec}$ 後からは, 流入した砂は沈積することなく, 先に沈 着している砂の上を水平に流動していくようになった。図 43はそのときの状熊を示す。とのときからあとは，流入した砂 は全部キ裂の奥の方に流動して砂のまだ高くなっていないとて ろに沈積し，砂のタイ積はしだいに奥の方へ延びていった。 图 4-4 は流入開始 $4 \mathrm{~min}$ 後の状萔を示す。砂が沈積せずに 水平に流動するようになったあとは，タイ積した砂の頂部とキ 裂の上端との閪䧣は変化しなくなったので，ての部分の断面皘 と，水の流入レートから，ての場合の平衡速度を計算するとと ができた。すはわち，

$$
\begin{aligned}
V_{e}=\frac{Q}{A_{e}}= & \frac{27.2}{0.8}=38.8 \mathrm{~cm} / \mathrm{sec}=1.27 \mathrm{ft} / \mathrm{sec} \\
\text { ここに } & V_{e} \text { は平衡速度 } \\
& Q \text { は水の流入レート } 27.2 \mathrm{cc} / \mathrm{sec} \\
& A_{e} \text { は砂の上のすいている 部分の断面積 } \\
& 0.8 \mathrm{~cm}^{2}
\end{aligned}
$$

\begin{tabular}{|c|c|c|c|c|}
\hline 砂のサイズ & $\begin{array}{l}\text { 水の流入V- } \\
1 \quad \text { cc/sec }\end{array}$ & 砂の混入率 & $\begin{array}{l}\text { 平衡速度 } \\
\mathrm{cm} / \mathrm{sec}\end{array}$ & 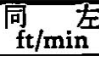 \\
\hline $10 \sim 20$ & 27.2 & $235 \mathrm{~g} / L(1.96 \mathrm{lb} / \mathrm{gal})$ & 38.8 & 76.2 \\
\hline $20 \sim 30$ & 25.3 & $118 \quad 0.98$ & 36.1 & 70.8 \\
\hline $30 \sim 40$ & 27.8 & $125 \quad(1.04$ & 32.9 & 64.5 \\
\hline
\end{tabular}

他のサイズの砂についても実験の推移はほとんど同じであっ た。それらの結果をまとめると次の表のとおりである。

表 5 水と砂を混合して流入した場合の平衡速度

この表で見ると，砂のサイズが小さくなるにつれて平衡速度も 小さくなる。すなわち沈殿しにくい，逆にいえば，砂粒が大き いほど䬺しやすい傾向が表われている。

実験第 2 あらかしめめキ裂内に砂のタイ皘を作っておいて水 を流入した場合

との実験は実験方法の項で述べたように，あらかじめキ裂模 型の中に砂を充テンしておいて，砂を混合しないで水のみを流 入して砂の流動状況からその平衡速度を求めた。これは，先の 実験では砂の混合装置の操作の関係で，水の流入レートをあま り上げるととができなかったので，仯の混入をやめるととによ って，水の流入レートを高くしようと若えたのである。すなわ ち、キ裂の中にあらかじめ水を㴖たしておき，キ裂の中央部の上 端にあけた孔を通じてキ裂の中に砂を落下させ, 砂がしだいに タイ積してピラミット状にその頂点がキ裂の上端にまで達する ように砂を充テンした。充テンの途中で何回か装置に適当な振 陲を与えて砂のタイ積の安定がよくなるように注意した。図 $\mathbf{5}$ -1 はその砂の允テン状況を示す。今回も実験第 1 の場合と同 せく，久の浜ヶイ砂の $10 \sim 20,20 \sim 30,30 \sim 40$ メッシュの3 種類の砂を使ったが，ての場合も，実跧の推移は各サイズの砂 全部ほほ同様であったので, 10〜20メッシュの砂の実験につ いてその概略を述べ, 他のサイズの砂については記録を表示す るだけにとどめるととにする。

上記のように 10 20メッシュの砂を実験装置の中に充テン

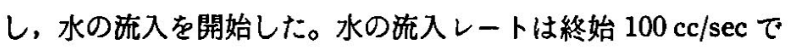
実験第 1 の場合に比して約 4 倍のレートだった。水の流入をは じるとただちに，砂のタイ積の頂部が削り取られ，そこに水 


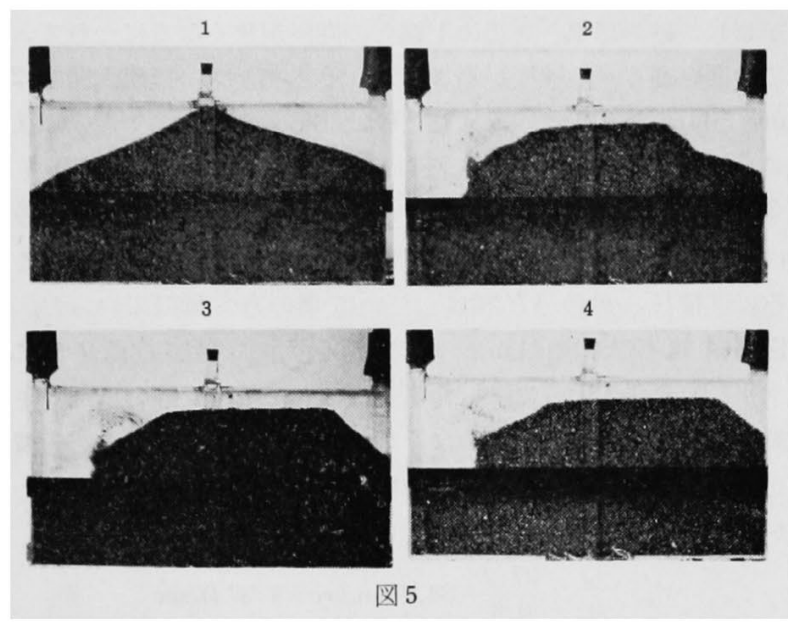

の通路が作られた。水流入 $30 \mathrm{sec}$ 後の状況を図 5-2 に示 寸。砂のタイ皘の上の水の流速が平衡速度より大きいので，夕 イ皘の頂部の砂はしだいに流され，タイ積の高さはしだいに削 られた。そしてほほ $1 \mathrm{~min}$ 後にはタイ積の上の水の流速が平衡 速度に等しくなって，それ以後は砂は流れ去らなくなった。て のときの状態を図 5-3 に示す。したがっててのときよりあ とには，砂のタイ積の高さは変らなくはった。图 5-4には水 の流入開始 $3 \mathrm{~min}$ 後の状態を示す。とれらの写真に現われて いるように，水がキ裂の中に流入したときの䇢いで砂のタイ積 のすその方があおられて砂がまき上げられ，てれが少量ずつ夕 イ積の頂部に流れ込んだが，との砂は平衡速度に達した後は全 部タイ積の頂部を越えてそのまま先の方に流れ去った。平衡速 度に達した後に, 水を流入させながら, 砂のタイ積の上部のお いていろ部分の高さを測り，水の流動面積を求めて，とのとき の平衡速度を計算した。実験は 2 度行ない, その平均值を求め たととろ $37.1 \mathrm{~cm} / \mathrm{sec}$ であった。

20〜30 メッシュ，30〜40 メッシュの仯についても同様に実 釦を行なった。その結果は表6のとおりであった。

表 6 砂を混入しない場合の水に対する平衡速度

\begin{tabular}{l|c|c|c}
\hline 砂のサイズ & 水の流入レート & 平衡速度 $\mathrm{cm} / \mathrm{sec}$ & 同 \\
\hline $10 \sim 20$ 左 $\mathrm{ft} / \mathrm{min}$ \\
$20 \sim 30$ & $100 \mathrm{cc} / \mathrm{sec}$ & 37.1 & 73.0 \\
$30 \sim 40$ & 100 & 36.1 & 71.1 \\
\hline
\end{tabular}

砂の混入率と平衡速度との関俰は, 砂の泥入率が大きいほ ど，寸なわち砂が多量に混入されるほど既しやすくなる。い いかえれば平衡速度か大きくなるものと考元られている。しか し, 上記の実験で実験第 1 は 118 ないし $235 \mathrm{~g} / l$ (1ないし 2 lb/gal) の砂を混入し，実験第 2 ではほとんど砂を混入してい ない(ここにほとんどという言葉を使ったのは，砂は全く混入 しなかったが，水にあおられてまき上げられた若干の砂か砂の タイ皘の上に流れ込んだので，てれがわずかながら砂を混入し たと同じ效果を及ぼしたかもしれないと思うからである)。そ してての雨者の実臨結果を表 5 と表 6 によって比較してみ ると, 10〜20メッシュの砂については後者のほうがさくな り, 20〜30 メッシュの砂については全く同じで，30〜40メッ シュの仯においては後者のはうが逆に大きくなっている。した がって,てれらの結果からみれば, 砂の混入率が平衡速度に及

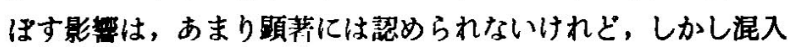

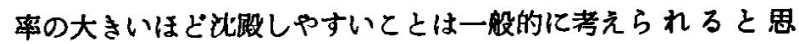
亏。

\section{2 中尊原油を流体とした場合の平衡速度の一列}

八橋油田の原油のような中質の原油を流体として用いた場合 の平衡速度を実験的に求めようと考えたが，原油は不透明なた めに砂の運動の状況を観察するととがでさず，したがって平衡 速度を求めることが不可能である。そとで透明な軽油（比重 0.806 , 粘度 $15^{\circ} \mathrm{C}$ にて $1.87 \mathrm{cp}$ ) を用いて, てれに粘度を增す ために機械油（比重 0.919 , 粘度 $15^{\circ} \mathrm{C} に 223 \mathrm{cp}$ ) と, 比重 をつけるために四塩化炭素 (比重 1.612 , 粘度 $15^{\circ} \mathrm{C}$ にて 1.05 cp) を適当に混合して比重 0.904 , 粘度 $15^{\circ} \mathrm{C} に 3.00 \mathrm{cp} の$ 油を作り，乙れを中䨘原油に代用して平衡速度を測定した。

実験装置の略図を図 6 に示す。キ裂の模型は 3.1 .1 にて説 明したものと同じのを使用した。図 6 で観測室と記してあ ろのがそれである。水の場合には水道を用いて一定の流量の水 を得たのであるが，油を流体に用いる場合には水道のようなも のはないので, 压搾空気を用い, 水銀レギェレーターにて一定 の圧力に保ちつつ貯油槽内の油を空気によって加圧して一定の 流量の油の流れを作った。

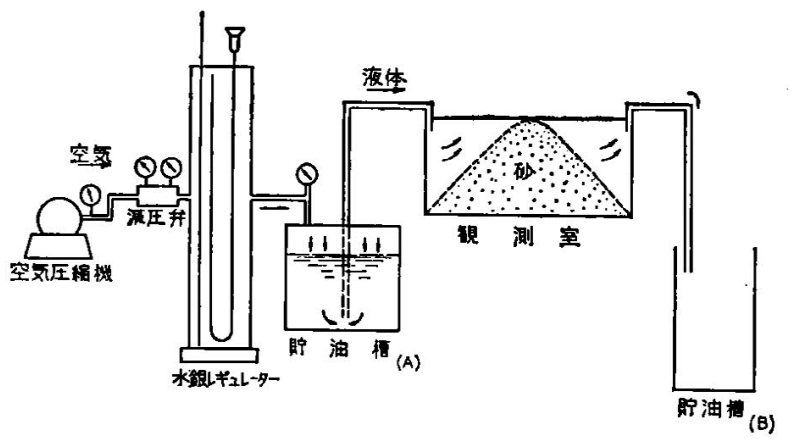

四6 实験装置 略四

実験のやり方は 3.1.2 の場合と同じく，おらかじめ油を満 たしたキ裂の中に砂をピラミット状に積み上げてキ裂の頂部に まで達しさせておう，水銀柱 $90 \mathrm{~mm}$ の空気圧にて眝油槽内の 油を押し出し $100 \mathrm{cc} / \mathrm{sec}$ のレートで油を流して砂のタイ積の上 部の油の流れが仯を運ばなくなったときのとの部分における油 の流速を测って平衡速度とした。

使用した砂は水の場合と同しく 久, 久の浜ヶイ砂の $10 \sim 20$ メ ッシュ, 20〜30メッシュおよび30〜40メッシュの 3 種類で, それぞれ 3 回ずつ実験を行なってその平均值を求めたのである が, その絬果は, 10〜20メッシュの砂については $83.3 \mathrm{~cm} / \mathrm{sec,}$

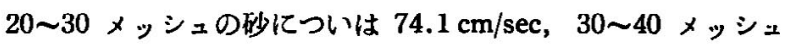
の砂については $66.7 \mathrm{~cm} / \mathrm{sec}$ という平衡速度の值を得た。

油を流体とした場合でも砂の粒が大きななるつれて平衡速 度が大きくなる。すなわち沈殿しやすくなる傾向を明瞭に示し てわり，水で実臨した場合とよく合致する。

なお水を流体とした場合に比較して，油を流体とした場合は 平衡速度の值がかなり大きくなってきており，粘度の高い流体 を使う場合のほうが砂が沈殿しやすいという絬果を示している が，乙れは粘度の高い油のほうか㵇流になりにくく，乱流をお こすためには大きな速度が必要であるてとを示しているものと 考えられる。

\section{3 キ裂内における砂の沈栍について}


今までに述べたととろの実験絬果は，垂通のキ裂における秒 の流動について行なったものであるが，これらの結果を水平の キ裂にそのままあてはめて，水平のキ裂におけろ砂の沈積状況 を数字的に求めてみた。一般に fracturing によって生ずるキ 裂は油層の㬝理の関係から水平に生ずるのが多くて垂直なキ裂 はまれであるとされているから，水平なキ裂の中の砂の流䡃な らびに沈皘の状況をしらべることはたいせつなととである。

さて，キ裂の中の砂の沈皘状況を考えるにあたって，次のこ とを仮定した。

(1) キ裂の厚さはすべて一様である。

（2）裂は水平に，しか子放射状にできている。

（3）フラっ液はキ裂の中で上下の地層に fluid loss をわこ さない。

（4）フラク夜はキ裂の中で radial flow を行ない，また㳘 入レートは一定である。

一般にキ裂内にわける流入レートと流速の関係を炊の式であら わされる。

$Q=2 \pi r H \cdot V$

ここに $Q$ は流入レート $\mathrm{cc} / \mathrm{sec}$

$r$ は坑心よりの距部 $\mathrm{cm}$

$H$ はキ裂の厚さ $\mathrm{cm}$

$V$ は流速 $\mathrm{cm} / \mathrm{sec}$

(6) 式より

$$
V=\frac{Q}{2 \pi H r}
$$

今平衡速度を $V_{e}$ ，平衡速度に達した位置の坑心よりの距锥を r。とすれば

$$
V_{e}=\frac{Q}{2 \pi H r_{e}}
$$

今, 坑心より任意の距㺟 $r$ にわりる流速を $V$ とすると， $V$ が $V_{\boldsymbol{B}}$ よりも大きいときには，砂は吏段するととなく流動し去 る。しかし流速は半径に反比例するので，坑心よりの距離が きくなるにつれてしだいに流速が小さくなり，つに $V_{e}$ の值 と等しくなると，との染から砂の此積がはじまる。炏にVが $V_{e}$ よりも小さいときには，砂は沈積し，このときに沈積した 砂の高さを $h$ とすれば

$$
V=\frac{Q}{2 \pi r(H-h)}
$$

砂の氿積がつついて くなり、つい $V=V_{e}$ となるまで砂の沈積はつづけられる。 とのときの砂の妀積する高さ $h$ と距離 $r$ との関係は次のように なる。すなわち（9）式において $V=V_{e}$ として

$$
V=\frac{Q}{2 \pi r(H-h)}
$$

ゆえに $h=H-\frac{Q}{2 \pi V_{\theta}} \cdot \frac{1}{r}\left(た た ゙ し ~ r \geqq r_{e}\right)$

との (10) 式によって坑心からの距離 $r$ と砂の沈積する高さ $h$ との関係を求めることができる。

\section{中兵原油を流体とした場合のキ裂内の站の沈科の一例}

3.2 亿て述へたとてろの中質原油の一例の実䙴によって得ら れた平衡速度の值を用いてキ裂内の $r$ と $h$ との関係を求めてみ た。キ裂の厚さは $H=0.5 \mathrm{~cm}, 1 \mathrm{~cm}, 3 \mathrm{~cm}$ の 3 種類とし,久 の捠ケイ砂 10〜20メッシュ, 20〜30 メッシュ, 30〜40メッ
表 7 中質原油を流体とした塻合の砂の沈櫝の一例

\begin{tabular}{|c|c|c|c|c|c|}
\hline 155 & 0 & 57 & 0 & 19 & 0 \\
\hline 130 & 0.060 & 70 & 0.182 & 30 & 1.091 \\
\hline 150 & 0.118 & 100 & 0.427 & 50 & 1.855 \\
\hline 200 & 0.214 & 150 & 0.608 & 70 & 2.182 \\
\hline 250 & 0.271 & 200 & 0.714 & 100 & $2.42 \%$ \\
\hline 300 & 0.309 & 250 & 0.771 & 150 & 2.618 \\
\hline 350 & 0.336 & 300 & 0.809 & 200 & 2.714 \\
\hline 400 & 0.357 & 400 & 0.857 & 250 & 2.771 \\
\hline \multicolumn{6}{|c|}{ 30〜 40 メッシニの砂について $\left(V_{e}=66.7 \mathrm{~cm} / \mathrm{sec}\right)$} \\
\hline 126 & 0 & 63 & 0 & 21 & 0 \\
\hline 140 & 0.048 & 80 & 0.210 & 30 & 0.893 \\
\hline 160 & 0.105 & 100 & 0.368 & 50 & 1.753 \\
\hline 180 & 0.149 & 150 & 0.579 & 70 & 2.097 \\
\hline 200 & 0.184 & 200 & 0.684 & 100 & 2.368 \\
\hline 250 & 0.247 & 250 & 0.748 & 150 & 2.579 \\
\hline 300 & 0.289 & 300 & 0.789 & 200 & 2.684 \\
\hline 400 & 0.342 & 400 & 0.842 & 250 & 2.747 \\
\hline
\end{tabular}
坑心よりの距蜼と沈積の高さとの関係

\begin{tabular}{c|r|r|r|r|r}
\hline \multicolumn{2}{c|}{$H=0.5 \mathrm{~cm}$} & \multicolumn{2}{|c|}{$H=1 \mathrm{~cm}$} & \multicolumn{2}{c}{$H=3 \mathrm{~cm}$} \\
\hline$r \mathrm{~cm}$ & $h \mathrm{~cm}$ & $r \mathrm{~cm}$ & $h \mathrm{~cm}$ & $r \mathrm{~cm}$ & $h \mathrm{~cm}$ \\
\hline $10 \sim 20$ & メッシ=の砂について & $\left(V_{\mathrm{e}}=83.3 \mathrm{~cm} / \mathrm{sec}\right)$ & \\
101 & 0 & 51 & 0 & 17 & 0 \\
110 & 0.040 & 60 & 0.156 & 30 & 1.313 \\
130 & 0.111 & 80 & 0.367 & 50 & 1.988 \\
150 & 0.163 & 100 & 0.494 & 70 & 2.277 \\
200 & 0.247 & 150 & 0.663 & 100 & 2.494 \\
250 & 0.299 & 200 & 0.747 & 150 & 2.663 \\
300 & 0.331 & 250 & 0.798 & 200 & 2.747 \\
400 & 0.374 & 300 & 0.831 & 250 & 2.798 \\
\hline
\end{tabular}

20〜30 メッシュの砂について $\left(V_{\mathrm{e}}=74.1 \mathrm{~cm} / \mathrm{sec}\right)$

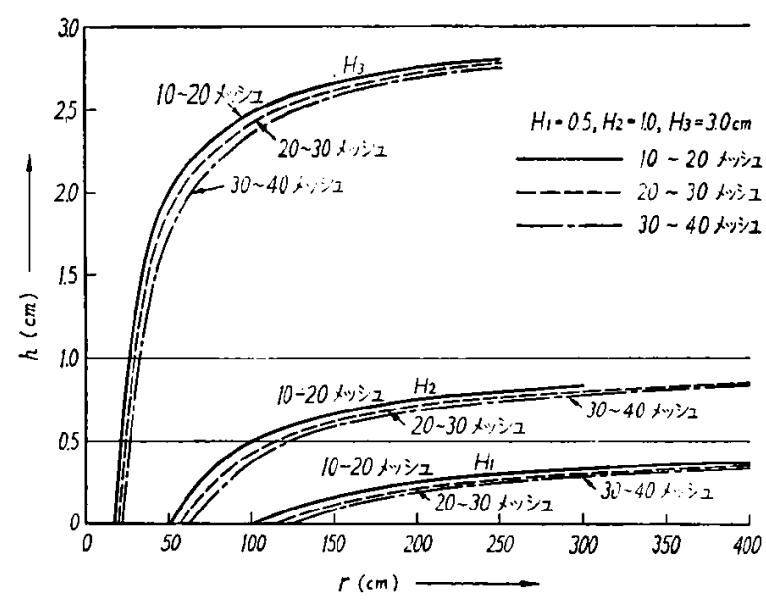

図 $7 \quad r$ と $h$ の関俰（中質原油の場合）

シュについてそれぞれ計筫した維果を表 7 おび图 1 に示 す。キ裂内の流れのレート（すなわち fracturing の圧入レー ト)は, $Q=10 \mathrm{bbl} / \mathrm{min}(26.5 \mathrm{l} / \mathrm{sec})$ とした。

この表によれば，たと元ば 30〜40メッシュの砂の場合，厚 さ $3 \mathrm{~cm} の \neq$ 裂ができたときには，坑壁付近は流速が平衡速度 以上なので，砂は全く沈殿せずにキ裂の奥の方へと流れ去る。 坑壁より奥にはいるにつれて流速が小さくなり，坑心から21 cm の距離においてはじめて流速が洋衡速度に等しくなって砂 が沈積をはじめる。しかし少し沈皘すればその部分の流速が评 衡速度を越えるのでそれからあと站砂は全部キ裂の奥に硫れ去 
る。たとえば坑心より $50 \mathrm{~cm}$ の位置では砂が $1.753 \mathrm{~cm}$ の高 さにな机ばそれ以上は炕積しないで，おとの砂は全部裂の奥 の方に流れ去るのであろ。このようにして坑心より $1.5 \mathrm{~m} の$ 距離でもなお攸の独積の高さ $2.6 \mathrm{~cm}$ 弱で，キ裂の上側との 間に約 $4 \mathrm{~mm}$ のすきまのできているととがわかる。

\section{ゲルを流体に使った場合のキ裂内の杪の沈棈}

日本における fracturingは最近はとんど全部フラク流体とし て原油ゲルを用いているので，最も多く使われている八橋原计 ゲルを流体とした場合についてキ裂内の砂の沈積の状沉を柃討 してみたいのであるが原油ゲルを用いて平衡速度を実験的に求 めるととは実験䒾置の関係上不可能だったのでアメリカにおい て水を基にしたゲルを流体とした場合の平衙速度を実験的に求 めた記録2)を借用してその数值を用いてゲルを流体としたとき

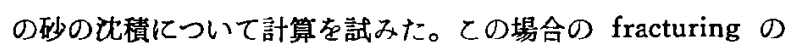
圧入レートは $15 \mathrm{bbl} / \mathrm{min}(39.7 \mathrm{l} / \mathrm{sec})$ とし, 裂の厚さは $H=$ $0.5 \mathrm{~cm}, 1 \mathrm{~cm}$ および $3 \mathrm{~cm}$ とし, 久の浜ケイ砂の $20 \sim 30$ × ッシュのものを用いた。その䋐を表8および図8 亿示 す。

表 8 ゲルを流体とした場合の秒の沈積の一例 坑心よりの距岱と沈積の高さとの関釈

\begin{tabular}{|c|c|c|c|c|c|}
\hline \multicolumn{2}{|c|}{$H=0.5 \mathrm{~cm}$} & \multicolumn{2}{|c|}{$H=1 \mathrm{~cm}$} & \multicolumn{2}{|c|}{$H=3 \mathrm{~cm}$} \\
\hline$r \mathrm{~cm}$ & $h \mathrm{~cm}$ & $r \mathrm{~cm}$ & $h \mathrm{~cm}$ & $r \mathbf{c m}$ & $h \mathrm{~cm}$ \\
\hline 45 & 0 & 22.6 & 0 & 7.5 & 0 \\
\hline 60 & 0.124 & 30 & 0.247 & 15 & 1.494 \\
\hline 80 & 0.218 & 50 & 0.548 & 30 & 2.247 \\
\hline 100 & 0.274 & 80 & 0.718 & 50 & 2.549 \\
\hline 150 & 0.349 & 100 & 0.774 & 100 & 2.774 \\
\hline 200 & 0.387 & 150 & 0.849 & 150 & 2.849 \\
\hline 250 & 0.410 & 200 & 0.887 & 200 & 2.887 \\
\hline \multirow[t]{3}{*}{300} & 0.425 & 300 & 0.925 & 300 & 2.925 \\
\hline & \multicolumn{3}{|c|}{$V_{\mathrm{s}}=280 \mathrm{~cm} / \mathrm{sec}$} & & \\
\hline & \multicolumn{3}{|c|}{ 砂は 20〜30 メッシュ } & & \\
\hline
\end{tabular}

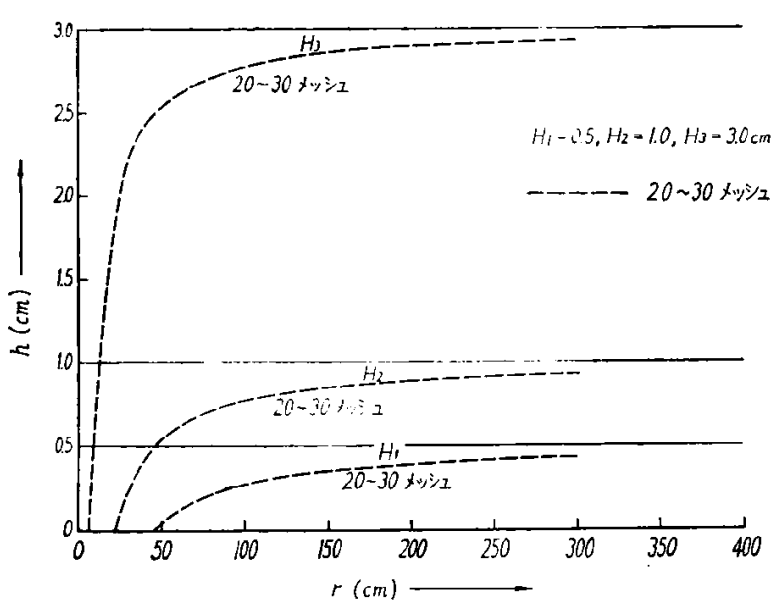

因 $8 r$ とんの関係（ゲルを流体とした場合）

との表によってみると，たとえば厚さ $3 \mathrm{~cm}$ のキ刘ができた 場合には，坑壁付近には流速か汗衡速度以上なので，砂は沈殿 せずにキ裂の奥の方に流れ去るか，坑壁より $7.5 \mathrm{~cm}$ 秋にはい ったとこらで平鮒速度に等しくなるのでこの点から砂の沈殿が はじまる。先に述べた中質原油を流体に用いたときに比して， 圧入レートが大きくなっているにもかかわらす，砂の沈積が早 くはしまるのは,ゲルの平衡速度が原油に比して大きいからで
ある。原讫の場合と同しようにキ裂の奥の方へゆくにしたがっ て砂の沈筫が高くなるが，ゲルの場合は砂の沈積が早く，坑心

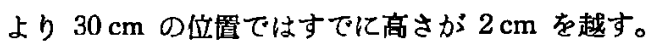

なお，以上の検討はフラク液の fluid loss がないものとして 考光たが，実際には fluid lossがあって，このためキ裂内の流 速がその分だけ小さくなるから，砂の沈積は実際にはもっとす みやかに起るものと考皇られる。

\section{4 キ裂内における砂の流動についての一般的考察}

今まで近べたとてろの実晾ならびに理論的榆討を基にして， fracturing の際のキ裂の中の砂の流動ならびに洮積の状沅を考 察し、さらにとれを基にして, fracturing の効果に影暗のある 2,3 事項についての榆討を試みる。

\section{キ裂内の秒の流動と沈積}

現在われわれが行なっている fracturing の作業では fracturing によって作られたキ裂の入口，すなわち坑壁の付近では， フラク液の流速は常に平衡速度を超過しているものと考えられ る。一般にキ裂は，前押し流体の圧入によって作られると考元ら おらかから，砂が裂の入口に到着したときには，裂はかなり 奥の宄まで作られており，砂はフラク液の流れに乗って，その ままキ裂の中に流れ込む。キ裂の奥にはいるにつ机て，流動面 積がさくなるから坑壁よりの距離に反比例して, 流速は小さ くなり，ついにある点にお゙いて，流速が平衡速度に等しくなる と，それから先は砂の沈積がはじまる。仯の炕積が起ると，流

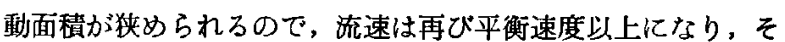
れ以後は，その地点にすいては仯の沈積は起らず，あとから来 た砂は全部キ裂の奥に流れ去る。このようにしてしたいい砂は キ裂の挟の方に向って順次高くタイ積するが，キ裂の入口に近 い地点, いいかえ机ば坑壁に近いキ裂の中には砂は最後まで沈 積しない。

以上の状況を考えるときに，特に注意を引くととは，第 1 亿 fracturing の秒は先に入机たものがキ裂の奥の方にはいり，あ とから入れたものがキ裂の入口に近く充テンされるものと考え られやすいが，実際にはその反対で fracturing の砂はあ己か ら入れたものほど，丰裂の奥の方にはいること，第 2 に，裂 の入口付近における流速が平衡速度よりも大きいと, 最後まで キ裂の入口付近には砂の沈積が起らぬととである。

\section{後押し流体の圧入レートを低くすること}

Fracturing によって油層に十分に大きなキ裂を作るために は、フラク流体をできるだけ高圧高速で圧入するてとか望まし く，そのために近年 fracturing の圧入装頨はますます大規模 のものになってきて，压入量も匡入レートも年をおって大きく なってきているが，キ裂の中の砂の流動と沈積の状沉から滋え ると，後押しの流体すなわち fracturing の最後に近いときに圧 入する流体は压入レートをあまり大るくしないととが望まし い。なんとなれば, fracturing 作業中は压入レートが大きいた めに，坑壁に近いキ裂の中では流速が平衡速度を越えているの で，fracturing の仯は沈皘するととができず全部キ裂の奥の方 に流れ込んでしまう。したがって，もし最後までのように 高い圧入レートで压入すれば，結局砂は全部キ裂の奥の方には いってしまって，最もたいせつな坑壁付近のキ裂の中には砂の 充テンがなく，fracturing の圧力がなくなればキ裂は元に戻っ てふさがってしまうのである。そこで，この現象を防ぐために 
fracturing の最後に近くなったとき，すなわち 後押し流体の 圧入のときにしだいに圧入レートを下げて，キ裂の入口におい て流速が可衡速度以下になるようにする必要がある。かように すれば，砂はキ裂の中全体にその入口の部分にまで完全に充テ ンして, fracturing の目的を達成するととができるものと考元 られる。

\section{Fracturing の钞の最後に大佳の䟞を送入すること}

Fracturingの砂の最後任往の大きい砂を送入して，キ裂の入 口の付近の曼透率を大きくすることは fracturing の効果を增 大する上にははとんど影辢がない。すなわち，浸透率 250 ダー シーの秒をキ裂の中に充テンし，最後にキ裂の入口付近に浸透 率 800 ダーシーの砂を充テンした場合を考えてみても，産油能 力の增加率は浸透率 250 ダーシ一の砂のみの場合に比してほと んど大差がないととが計算上明らかれされている。その上，前 項で述べたように，fracturing の压入レートが終始変らないと きには，あとから送入された砂は先に沈積した砂の上を流れ越 してキ裂の奥の方にはいる傾向があるから， fracturing の砂の 最後に大往の砂を送入しても，との砂はキ裂の奥の方にはい。 てしまって，裂の入口の浸透率を大きくするてとに待立た ない。

しかしながら，fracturing の最後に烽の大きい秒を送入する ことは，次に述へるような考虑のもとに行なった場合には fracturing の効果を高める上に重要な役目を果すてとができる と考えられる。すなわち，前項で述べたように，fracturing の 印入レートが沂来著しく高められてきた結果，キ裂の入口付近 では流速が平衡速度を越兄ているのでてのままではキ裂の入口 付近に砂の此皘が起らない。そてでキ裂の入口付近䛃完傜 を充テンするためには fracturing 作業の終りに近づくにつれ て压入レートを下げる必要があるが，てのときに经の大きい砂 を送入すれば，3.1 の実験䎲よって明らかなように，砂の径が 大きくなるとその平衡速度か大きくなる。いいかえれば砂の沈 即が起りやすくなるので，キ裂の入口付近敒砂の沈積が起りや すくなる。すなわち fracturing の最後に大径の砂を送入する ことと，压入レートを低くすることによって，キ裂の入口にま で十分に砂を充テンするととができるようになると考えられる のである。

\section{Over fluch の効果}

Fracturing の最後に圧入するところの砂を含まない後押し流 体の圧入量が多すきて，キ裂の中にての砂を混入しない流体が 压入されることを Over fluch というが，とれが fracturing の 効果にどのように影䇾するかを考元てみる。

一般的にいって，砂の混入率か低いほど平衡速度は小さくな る。したがって砂を混入しない压入流体は砂を混入した場合に くらへてて平衡速度がさいのて，砂を泿入して圧入している間 にキ裂の中に沈積した砂は，砂を混入しない流体の圧入がはし まろと再び流机はしめて裂の奥の方にはいってしまう。した がって fracturing によってキ裂の入口付近につくられた砂の
讪䅡が over flush によって再ひ洗い流されてしまい，その部 分のキ裂の中は汃らとなってしまうことがある。ての結果は fracturing によって作られたキ裂が fracturing のあとで，そ の入口付近が再び閉ソクしてしまうことになり，fracturing の 効果を著しく娍殺するととになるのである。また，原油ゲルは原 油よりも製作費が滈くつくために，一般にフラク流体には原油 ゲルを用い，後押し流体汇法原油そのままを使用するととが多 いが，原油を流体江用いる場合の平衡速度は原神ゲルを用いる 場合に比してはるか汃小さいので，原油ゲルを流体汇用いて作 られた砂の沈積を，砂を含まない原油の後押し流体で over flush すれば，沈積している砂がはなはだしく洗い流されてしまう。 したがって，いずれの場合でも， over flush は逢けるように注 意しなければならないが，後押し流体に原神を用いたときには， 特に over flush の害が大いてとに注意するを要しなお， できれば後押し流体にす原油ゲルを用いるととが望ましいので ある。

\section{Fracturing の効果かすくない場合の一つの考え方}

Fracturingを行なって, 压入量, 压入レート，压力のかかり 方および砂のはいり方など，すべての点について良好に行なわ れたにもかかわらず，fracturing の効果があまりよくないとい うような例はしばしば経䍄するとてろであるが，ての場合に今 まで述べた各種の状況を类元てみる必要のあるてとがある。す なわち，殴入の最後まで坑壁付近のキ裂の中の流速か平衡速度 よりも大きくて，キ裂の入口付近仯が充テンしなかった場合 でも，また over flush でキ裂の入口付近の砂を洗い流してし まったときでも，地上にいて得られる記録には異状がないてと が多く，压入量，圧入レート，圧力のかかかり方および砂のはいり 方，いずれも満足すべき状態で fracturing としては成功した ようにみ元る。しかるに実際には，せっかく fracturing によ って作られだ裂も，その入口付近に砂か㳘テンされておらな いために fracturing の生入がなくなればキ裂は再ひ閉してて まって, fracturing の効果は全く减殺されてしまうのである。 したがって理由がよくかからないで fracturing の効果がない ときには，以上述へたような現象か起っているてとを考えてと れを避ける手段を講して fracturing を試みてみる必要がある のである。との問題関しては，今後たくさんの実際作業尗

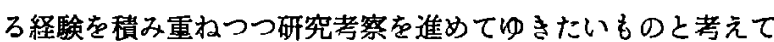
いる。

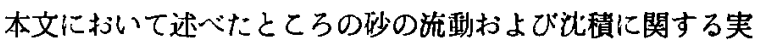
臨は，いずれも帝国石油（株）中央技術研究所代わいて行なす れたものであり，これに関し 同研究所第 3 砳究室空長 斉藤光 氏および同室研究員 南川 清, 手塚真知子, 笽川昭夫, 小林 一紀の諸氏の多大な御協力が得られたてとに対して，ててに深 甚なる感謝の意を表明するものである。

$$
\text { 考文 献 }
$$

1) 八田, 化学工学栍諭。

2) L.R. Kern, et al., J. Petrol. Tech., XI, (7), 55 (1959). 